\title{
Thirty Years On: Reading the Country and Indigenous Homeliness
}

\section{Ken Gelder}

The 2014 reprinting by re.press of Stephen Muecke, Krim Benterrak and Paddy Roe's Reading the Country: Introduction to Nomadology (first published 1984) is a useful reminder, thirty years on, of just how contemporary this remarkable book still is. ${ }^{1}$ Although it isn't 'anthropological' (and speaks in fact about the 'death of anthropology', a discipline from which it distances itself), Reading the Country nevertheless embarks on a journey with which anthropologists would be only too familiar: with Muecke getting into the car, driving out to a remote community in north-west Western Australia to encounter a Moroccan artist, Krim Benterrak, and a senior Aboriginal man, Paddy Roe, and talking and listening, transcribing, and then reflecting on what has been transcribed. The book is also an expression of male companionship - if we think of the meaning of 'companion', with bread - where three men (and, sometimes, others) come to know each other by sitting down together, and making spaces for each other, although in very different ways, with very different outcomes: stories and narratives, paintings, and various intellectual meditations on all this that drew extensively and specifically on Deleuze and Guattari's use of the term nomadology.

The emphasis in Reading the Country is on movement, tracking and travel; those moments of companionship therefore seem provisional, as if no one stays in the same place for very long. This is consistent with nomadology, which doesn't seem to encourage a reading that might by contrast place an 
emphasis on home, or homeliness. The only 'homestead' in Reading the Country belongs to the Roebuck Plains sheep station: while nomadology is tied to indigeneity, homesteads are understood as the outcome of colonialism and settlement. (I shall return to the word homestead later on.) On the other hand, in a narrative about making rain on the station, Paddy Roe remarks at one point, after some hard work: 'We go back home - / go back for dinner': ${ }^{2}$ a familiar homely image. Indigenous land ownership is cast in this way too, as it must be in modern Australia. Muecke talks occasionally about Paddy Roe's 'home country with which he has the closest links'. ${ }^{3}$ Roe is a welcoming host in this book, while Muecke and Benterrak are visitors or guests: 'Krim and I', Muecke writes, 'set up camp at Coconut Wells, on Paddy's block of land. Not only do Paddy Roe and Butcher Joe (Nangan) live here, but also various members of Paddy's family at different times.' ${ }^{4}$ In this account, Roe's home - and home countryis both colonised and hospitable.

Homeliness might seem like the opposite of nomadology. But here is another homely moment, this time in an article Muecke published much later on, called 'Visiting Aboriginal Australia'. ${ }^{5}$ Here, he thinks back to his first job in Perth in 1974-ten years before Reading the Country was publishedand recalls some bad but no doubt well-meaning advice from a senior anthropologist there: "Don't have anything to do with Aboriginal women", this man says, "or Aboriginal politics."' Muecke writes: 'I was embarrassed [by this advice], for only the other night I had been in Gloria's bath. When I moved into the Everett St flats, my hot water was out of action, so Gloria, immediate neighbour across the hall [an Indigenous woman], had invited me to use her tub.' ${ }^{\prime}$ Later, she offers Muecke a martini. This is another welcoming encounter ('visiting Aboriginal Australia') that might seem to be outside and even in contradistinction to the frame of Reading the Country: metropolitan, not remote; neighbourly, rather than to do with companionship; the host here is a woman, not a man; and the image is indeed homely, rather than nomadic.

I want to use this chapter to think about homeliness a little more, in the distant aftermath of an important book that had read Indigenous relations to country primarily through the 
concept of nomadology. Incidentally, the word Indigenous itself comes to Australia after the first publication of Reading the Country-Muecke himself never uses it-and of course it works to adjust the politics, and the cultural politics, of the word Aboriginal. It is therefore possible to say that Reading the Country is literally a way of registering the process of 'becoming Indigenous', which, as James Clifford has noted, involves a combination of relations to country that are both 'displaced' and 'sustained', combining the experience of dispossession and re-attachment. For Clifford, the combination of processes of movement, dislocation and homeliness also means that becoming Indigenous and being diasporic are therefore similar: as he puts it: 'In everyday practices of mobility and dwelling the line separating the diasporic from the Indigenous thickens: a complex borderland opens up.'7

It does generally seem as if Reading the Country-because of Muecke's many contributions to it - is dominated by a Deleuzean use of nomadology; but it isn't, not completely. A whole number of citations flow through the book, making it a sort of tool kit that readers - students, especially - will no doubt continue to enjoy: there's Deleuze and Guattari, but also Foucault, Baudrillard, Barthes and many others, even Dick Hebdige who, by the early 1980s, was an important figure for cultural studies. Muecke's project in Reading the Country was indeed a bit like Hebdige's on British punk, bringing a wide range of continental theory to bear on a social group in the hope of illuminating what they do, culturally speaking. (Muecke's work is more successful here, refusing to give up in the way Hebdige finally did; and of course, his project is ethnographic, while Hebdige's was certainly not.) Muecke drew on Hebdige for 'bricolage', channelling anthropology through cultural studies as he cast Aboriginal families in northwest Western Australia as do-it-yourself 'bricoleurs'. 8 The citation in fact takes us to Dick Hebdige on London's mod subculture: 'the mods', Hebdige writes, 'could be said to be functioning as bricoleurs'. The application of this citation to Aboriginal people in remote communities literally associates the process of 'becoming Indigenous' with becoming mod-or more broadly, becoming modern. It is also one of those many moments in Reading the Country where an actual social practice is tied to a 
critical method, a way of reading or encountering texts (which is how nomadology itself is understood):

for both Aboriginal and 'general' readers, there is a pleasure in the text of bricolage, a pleasure in seeing the edifice of language tremble a little as it becomes a kind of poetry. Bricolage is flexible, economical and unstable. It does not seek continuity or harmony in a world of discontinuity and inequality. It is functional rather than idealistic; it uses the wrong object for a useful purpose, but can change according to necessity. It suffers no illusions. It allows a goat to make her home in an abandoned car. ${ }^{9}$

This interesting passage ends, perhaps unexpectedly, with another homely image: the car that no longer goes anywhere, a domesticated animal (gendered female), and the idea of dwelling and of home-making - which speaks to what some commentators these days have been calling 'portable domesticity', a practice that brings dislocation, mobility and home-making into proximity with each other. ${ }^{10}$

Nomadology was always a bit impatient with homeliness, with the practice of stopping in one place. 'History is always written from the sedentary point of view', Deleuze and Guattari observed. 'What is lacking is a Nomadology, the opposite of a history.'11 But the nomadological emphasis on movement and travel always ran the risk either of romanticisation or appropriation, as many commentators have since observed. ${ }^{12}$ In the mid 199os, Rosi Braidotti had tied nomadology or nomadism to a kind of cosmopolitan, multilingual, romantically conceived feminism: 'As an intellectual style', she wrote in 1994, 'nomadism consists not so much in being homeless, as in being capable of recreating your home everywhere. The nomad carries his/her essential belongings with him/her wherever s/he goes and can recreate a home base anywhere.' 13 This is another expression of portable domesticity, reminding us of just how entwined nomadology and homeliness can be. James Clifford had written about 'dwelling and travelling; travelling-in-dwelling, dwelling-intravelling' in his earlier book, Routes: Travel and Translation in the Late Twentieth Century; he goes on to ask, 'What are the 
political stakes in claiming (or sometimes being relegated to) a "home"?'14

Since nomadology, cultural criticism over the last twentyfive years or so has returned again and again to the question of home and homeliness. Think of the geographer Doreen Massey, for example, and her interest in 'place' as a 'point of intersection', a 'meeting place' (a place of companionship) which looks both inward and outward: 'which is extroverted' and 'includes a consciousness of its links with the wider world'. ${ }^{15}$ This is place becoming modern, defined as much by those who don't live there (visitors, tourists, anthropologists, and so on) as those who do. The question is, as David Morley puts it, why in the midst of all this 'particular people stay at home' and 'how, in a world of flux, forms of collective dwelling are sustained and reinvented'. 16

Becoming Indigenous is also a matter of becoming modern: where the experiences of dislocation and dispossession underwrite, and shape, expressions of attachment to land. This binary has of course been remarkably influential in Australia, structuring the ways in which Indigenous Australians and their various claims on the nation - to land, to children, and so on - are recognised and understood. In anthropology, this can mean that Indigeneity is sometimes negatively conceived as a condition that can never be complete-in-itself, although I would add that it is hardly alone in this. This is what Elizabeth Povinelli suggests, for example, in her book The Cunning of Recognition: Indigenous Alterities and the Making of Australian Multiculturalism (2002):

At the most simple level, no indigenous subject can inhabit the temporal or spatial location to which indigenous identity refers - the geographical and social space and time of authentic Ab-originality ... Producing a present-tense indigenousness in which some failure is not a qualifying condition is discursively and materially impossible. ${ }^{17}$

Here, the idea of Indigeneity-in-(its)-place is not allowed; it is literally not quite at home in these remarks. One can see why Muecke in Reading the Country was ambivalent about anthropology. But it is also possible to see how the discursive shift 
from Aboriginal to Indigenous in the discipline of anthropology carries with it precisely this kind of structural adjustment, where 'becoming Indigenous' and 'becoming modern' inhabit the same space even as, together, they make the question of the inhabitation of place - we might say, of dwelling, or home, or even of settlement-one that is always in process and never fully realisable.

Muecke's work in Reading the Country knows very well that the anthropological binary of the settled (or sedentary) and the nomadic is a bit of a mixed blessing. As one of those people who all-too-casually tends to collapse nomadology into nomadism, I'm always inclined to think here of Henry Mayhew's famous (or notorious) introduction to London Labour and the London Poor from the early 186os, which saw nomadic 'tribes' flowing through the centre of a sedentary metropolis: itinerant, tied to territory but not property, ephemeral not permanent, and so on. The question of place or of settlement (who can claim it, who can't) becomes both contingent and essential here, just as it is when we think about Indigeneity in Australia in the aftermath of Reading the Country. In her earlier book, Labor's Lot: The Power, History and Culture of Aboriginal Action (1994), Elizabeth Povinelli had looked at the predicament of Indigenous women in several remote communities across the Northern Territory. A 'woman's voice is generally marginalised' by anthropologists, she notes:

but women map out connections to land, they govern in various ways, and so on. The emphasis in [Povinelli's] book is on dwelling or residency, on belonging to land as a matter of position and degree: Aboriginal women who had come to the Docker River settlement, for example, ask not who belongs there 'instead of someone else ... [but] who belonged there more than someone else?'18

'Whose Settlement - whose "country", Povinelli asks, 'is Docker River?',19 and in relation to what conceptual and legal frameworks? What I want to pause over here is precisely the use of that word settlement in the context of thinking about Indigenous relations to place. Usually, we use settlement 
in relation to settlers, to non-Indigenous colonials and postcolonials; and our postcolonial response to this is to talk at the same time about $u n$-settlement, about the capacity for settlement (under postcolonial conditions) to be something that can never fully be settled. Jane M. Jacobs and I wrote about this predicament at length in Uncanny Australia back in 1998, but the issue still seems to be trending even in these postpostcolonial times, and we can still see variations on it today. ${ }^{20}$ A good example is John Frow's recent essay in the Cultural Studies Review, titled 'Settlement', no less, which turns back to the Tonnesian notion of gemeinschaft (community) and to Georg Simmel's iconic figure of the stranger as a visitor from outside who-once he arrives - does not leave. ${ }^{21}$ Frow looks at Tommy McRae's remarkable 189os drawing of the escaped convict William Buckley's colonial encounter-and colonial exchange - with local Aboriginal people, and he sees it in terms of the way McRae presents Buckley as a settler who is nevertheless also a stranger: something more than a visitor, someone who seems, as Andrew Sayers puts it, almost to have 'bridged the (seemingly unbridgeable) gap between Aboriginal and settler society'.22 That is, Buckley is someone who - through his encounter with Aboriginal people - has 'left the world of white settlers' to become, literally, unsettled (a word that Frow repeats a number of times). Frow's view of the Aboriginal world Buckley enters is equivocal, however, because it is itself 'becoming modern' through the colonial encounter. That world, he writes, is 'not unproblematically a community'-although he adds that it is at the same time 'clearly, still, a community', as if that moment before 'becoming modern' cannot be let go of or forgotten: it is a place, but an extroverted place. ${ }^{23}$ McRae's drawing of Buckley with a group of Aboriginal people therefore gives us what Frow calls an image of 'settlement with the stranger', and it looks as if he means Aboriginal settlement here: where McRae's drawing appears to convey an Aboriginal world in which whites are accepted, as Frow puts it, 'almost as equals'. ${ }^{24}$

This is, of course, a benign view of colonial exchange and the colonial encounter, built around what is often now called in cultural studies and elsewhere 'convergence': where you look at otherwise divergent social groups to analyse those 
points or moments where they actually meet or come together: their points of intersection. It is an approach that has played itself out in various ways both before and after Reading the Country. Felicity Collins and Therese Davis's book, Australian Cinema After Mabo, opens by quoting Muecke on the 1977 film Backroads and its 'moments of exchange': where 'characters gain and lose identities, transferring and transforming cultural understandings'. ${ }^{25}$ Then they look at the films Rabbit-Proof Fence and Rolf de Heer's The Tracker, pursuing the figure of the stranger in the latter film through the relationship between what it calls the Tracker and the Follower:

The Follower becomes a stranger in The Tracker's eyes ... [Their] friendship ... is premised on a recognition of difference but one that allows for an ethics of hospitality. The Tracker is now recognised as the one who is "at home", welcoming The Follower to another's country where they are both strangers, or guests. ${ }^{26}$

In this passage, Indigeneity is understood through the figure of the stranger even when it is at home (a phrase that now finds itself in inverted commas: as if it, too, can never be at home with itself). It is a relational or relative condition, in other words, playing out precisely this entangled predicament of dislocation and homeliness. This is something that anthropology - in spite of everything - has understood very well. The Brazilian anthropologist Eduardo Viveiros de Castro is one among many others who has recently thought about the question of 'convergence', in an article titled 'The Relative Native': wondering in particular about whether anthropological knowledge applies concepts that are 'extrinsic to their object' (for example, applying Deleuze and Guattari's concept of nomadology or Hebdige's concept of bricolage to Aboriginal people in remote north-west Western Australia), or whether 'the procedures involved in anthropological investigation are of the same conceptual order as the procedures being investigated': that is, where what is 'extrinsic' somehow does indeed manage to converge with (rather than just, say, visit and leave) the object of study. ${ }^{27}$ 
I have been raising all these issues and processes 'becoming Indigenous' and 'becoming modern', convergence and the colonial or postcolonial encounter, the question of settlement and Indigeneity, the question of the home and Indigenous domesticity and so on - not least because I had been interested in a criticism made in 2012 of something Jane M. Jacobs and I wrote some years ago in our book Uncanny Australia - and for better or worse, I want to outline that criticism here. Alison Ravenscroft's book The Postcolonial Eye is in most respects the complete opposite of Reading the Country. Whereas Muecke, Benterrak and Roe invest in notions of companionship and hospitality and open up Aboriginal storytelling for discussion and circulation - making Aboriginal knowledges of land and place available to non-Aboriginal readers - Ravenscroft's book wants to set limits to all this: there are things non-Indigenous readers of Indigenous narratives, she insists, are not supposed to know, or cannot know. She wants to assert 'the idea of radical differences between white and Indigenous cultural forms': she is against 'convergence' because she wants to preserve Indigenous alterity (which means that her 'native' is not 'the relative native'). ${ }^{28}$

So her book is a sort of gatekeeping exercise, where (by, for example, stressing her intimacy with Indigenous writing rather than her companionship with Aboriginal people) she is somehow able to know what it is that non-Indigenous people cannot know. Her readings are therefore introverted, not extroverted - if I can draw again on Doreen Massey's description here. In a chapter about Uncanny Australia, Ravenscroft goes on to claim that Jacobs and I had inadvertently compromised the alterity of what she calls 'the Aboriginal subject'; and to make her argument, she looks at a story we read and commented on in our book, told by Percy Mumbulla and transcribed by Roland Robinson way back in 1958, called 'The Bunyip'. This story involves a marauding bunyip figure, which (as we say in our reading) turns up unannounced at Percy Mumbulla's parents' 'homestead' and has what we call an unhomely effect. In Simmel's terms, the bunyip is a stranger. Percy's mother and father are, as we note, unsettled by the bunyip's visit but they also negotiate with this figure (in 
'the language') and are able to remain in their place ('at home'). For Ravenscroft, however, we:

install an Aboriginal family at home, in place. This is not any old place, though; for Gelder and Jacobs this is the place of the white man. Gelder and Jacobs call the family's home a homestead, an extraordinary misnomer, for whoever heard of an Aboriginal family with a homestead?29

Ravenscroft then suggests that we compromise the alterity of this Indigenous family to such an extent that we represent them as if they are nothing less than (non-Indigenous) 'settlers': dwelling 'in the homestead', as she puts it, 'rather than [for example] on an "Aboriginal settlement". 30

I was interested here in the way that for Ravenscroft Indigenous people can inhabit an 'Aboriginal settlement' without being homely or 'at home' or (we might even say) 'in the home'- putting aside the banal fact that, in the story we are talking about, Percy Mumbulla's mum and dad are standing outside the home when the bunyip visits. Returning to the binary of the sedentary and the nomadic that is so important to nomadology and Reading the Country, we might then say that Ravenscroft wants Aboriginal people to be 'in place', even settled, but not 'at home' - a condition she ascribes only to settlers. The word homestead does, of course, have settler connotations, used in Reading the Country only to identify the sheep station on Roebuck Plains. But is this the only connotation it can have? Percy Mumbulla and his parents lived at Wallaga Lake Aboriginal settlement on the south coast of New South Wales. In May 1950, state government records tell us, 'work commenced on the construction [of] 15 houses for Aboriginal People, a store, recreation hall, school and roads'. ${ }^{31}$ Mark McKenna notes that Aboriginal people at Wallaga Lake 'had ... campaigned for better housing in the 1950s', writing petitions and so on; these campaigns were relatively successful. ${ }^{32} \mathrm{We}$ know very well that Aboriginal housing and state intervention have always been intimately entwined, where the boundaries between homeliness and the state (private lives and the public management of those lives) are routinely transgressed. This is another instance of the extroversion of place: someone, rather 
like the bunyip in Mumbulla's story, is always turning up and making demands, insisting on a response, asking for hospitality, and not always going away. This is what Peter Read says in the introduction to a collection of essays titled Settlement: A History of Australian Indigenous Housing (2000):

A cottage inhabited by an Aboriginal family ${ }^{33}$ was less a shelter than an instrument of management, education and control. It is not until, broadly, the entry of the Commonwealth government after the 1967 referendum that Aboriginal housing assumes its more recognisable form of providing shelter, a hearth, a refuge of affection and an armour of security. Many of the subsequent battles were fought over who, in the end, was to control accommodation and shelter. ${ }^{34}$

Helen Ross takes the title of her earlier book, Just for Living (1987), from a different perspective on Aboriginal housing, writing: 'While it is useful to know how [Aboriginal] people use, that is, live in, their houses, it is equally important to step back from the housing-centric view of affairs and consider how, even whether, housing plays a role in people's daily and whole lives'. ${ }^{35}$ 'For some Aboriginal people', she goes on, 'moving into a house and creating a sense of home there is a major aspiration. For others, the house is more incidental to their lives'. ${ }^{36}$

I certainly do not want to invest in a sense of Indigenous homeliness as some sort of utterly assimilated condition, of the kind that leads Ravenscroft to imply that we talked about this Aboriginal mother and father in the late 1950 os as if they were 'settlers': as if (forgetting the entanglement of becoming Indigenous and becoming modern) they were somehow not Indigenous at all. On the other hand, I do want to suggest that in the aftermath of Reading the Country-both despite and because of this book's emphasis on nomadology - it has been increasingly possible to conceptualise what might very well have once seemed like nomadology's opposite: that is, Indigenous homeliness and being-at-home. We can remember the colonial racism that thought, as Joseph Banks once did, that Aboriginal people didn't have a sense of land ownership not least because they didn't seem capable of building houses. 
Their shelters, Banks observed, were 'framed with less art or less industry than any habitations of human beings that probably the world can shew'. ${ }^{37}$ Following on from a long and violent history of Indigenous dispossession after colonisation, we can also remember the more recent histories of Aboriginal evictions from homes: for example, the 1997 Homeswest eviction of an Aboriginal family in Perth to which Quentin Beresford, among others, has drawn attention. ${ }^{38}$ We could also think about what is now called 'out of home care' for Indigenous children in state institutions, and what it means not to have a sense of being-in-the-home when Indigenous children are institutionalised by the state. And I also think we should not forget the question of nomadology when we think about Indigeneity 'at home'. In her essay 'Deleuze and Guattari at Muriel's Wedding', Meaghan Morris has reminded us of how these apparently opposite things are in fact folded together: where she reads the chapter before the one on nomadology in Deleuze and Guattari's A Thousand Plateaus, to think precisely about homeliness. As she puts it, 'homeliness follows the drawing of a circle round an "uncertain and fragile centre" ... home is in the middle of things ... neither origin nor destination, home is produced in an effort to organise a "limited space" that is never sealed in, and so it is not an enclosure but a way of going outside. ${ }^{39}$ If we think along these lines in particular, then perhaps we can read that image of the bunyip roaring at Percy Mumbulla's mum and dad as they stand outside their home - or 'homestead' - in a way that complicates, rather than flattens, these connections between settlement and unsettlement. And if we think like this, it may help us to consider more adequately-and less dismissivelywhat it might mean to 'become Indigenous' in the kind of 'limited space' that could be understood as a home.

\section{Notes}

1 Reading the Country was reprinted by re.press at the end of 2014, exactly thirty years after the date of its original publication. Stephen Muecke, Krim Benterrak and Paddy Roe, Reading the Country: Introduction to Nomadology, Fremantle Arts Centre Press, Fremantle; Stephen Muecke, Krim Benterrak and Paddy Roe, Reading the Country: Introduction to Nomadology, re.press, Melbourne 2014. In references to this work, page numbers refer to the Fremantle Arts Centre Press edition. 
Muecke, Benterrak and Roe, p. 85.

Ibid., p. 23.

Ibid., p. 26).

Stephen Muecke, 'Visiting Aboriginal Australia', Postcolonial Studies, vol. 2, no. 1, 1999, pp. 49-54.

Ibid., p. 49.

James Clifford, Returns: Becoming Indigenous in the Twenty-First Century, Harvard University Press, Cambridge, MA, 2013, p. 70.

Dick Hebdige, Subculture: The Meaning of Style, London and New York, Methuen, 1979, p.104.

Muecke, Benterrak and Roe, pp. 171-2.

See, for example, Janet C. Myers, Antipodal England: Emigration and Portable Domesticity in the Victorian Imagination, SUNY Press, Albany, NY, 2009.

Gilles Deleuze and Félix Guattari, A Thousand Plateaus: Capitalism and Schizophrenia, trans. Brian Massumi, London and New York, Continuum, 2004 p. 25.

See, for example, John K. Noyes, Ronald Bogue and others in a special issue of Interventions: International Journal of Postcolonial Studies, vol. 6, no. 2, 2004, devoted to a discussion of the uses, and usefulness, of nomadology and nomadism. Rosi Braidotti, Nomadic Subjects: Embodiment and Sexual Difference in Contemporary Feminist Theory, Columbia University Press, New York, 1994. p. 16. James Clifford, Routes: Travel and Translation in the Late Twentieth Century, Harvard University Press, Cambridge, MA, 1997, p. 36.

Doreen Massey, Space, Place and Gender, Polity Press, Cambridge, 1994, p. 155. David Morley, Home Territories: Media, Mobility and Identity, Routledge, London, 2002, p. 12.

Elizabeth Povinelli, The Cunning of Recognition: Indigenous Alterities and the Making of Australian Multiculturalism, Duke University Press, Durham, NC, 2002, p. 49.

Elizabeth Povinelli, Labor's Lot: The Power, History and Culture of Aboriginal Action, University of Chicago Press, Chicago, 1993, p. 43.

Ibid.

Ken Gelder and Jane M. Jacobs, Uncanny Australia: Sacredness and Identity in a Postcolonial Nation, Melbourne University Press, Melbourne, 1998.

John Frow, 'Settlement', Cultural Studies Review, vol. 18, no. 1, March 2012. <http://epress.lib.uts.edu.au/journals/index.php/csrj/article/view/1611> Andrew Sayers, Australian Art, Oxford University Press, Oxford, 2001, p. 75. Frow, p. 16.

Ibid.

Cited in Felicity Collins and Therese Davis, Australian Cinema After Mabo, Cambridge University Press, Melbourne, 2004, p. 166.

Ibid., p. 16.

7 Eduardo Viveiros De Castro, 'The Relative Native', HAU: Journal of Ethnographic Theory, vol. 3, no. 3, 2013, pp. 473-502, p. 477.

Alison Ravenscroft, The Postcolonial Eye: White Australian Desire and the Visual Field of Race, Ashgate Publishing Ltd, Farnham, UK, 2012, p. 2.

Ibid., p. 84. Ibid., p. 85 .

'Wallaga Lake Aboriginal Station', NSW Government State Records. $<$ http://search.records.nsw.gov.au/agencies/4143;jsessionid=220878F8EFEDDA3B A296864F73B8oAFE>

2 Mark McKenna, Looking for Blackfella's Point: An Australian History of Place, UNSW Press, Sydney, 2002, p. 172. 
33 An observation that might very well prompt Ravenscroft to ask, 'whoever heard of an Aboriginal family with a cottage?'

34 Peter Read, Settlement: A History of Australian Indigenous Housing, Aboriginal Studies Press, Canberra, 200o, p. 1.

35 Helen Ross, Just for Living: Aboriginal Perceptions of Housing in Northwest Australia, Canberra: Aboriginal Studies Press, 1987, p. 3.

36 Ibid., p. 13.

37 Cited in Kay Anderson and Colin Perrin, 'Beyond Savagery: The Limits of Australian "Aboriginalism", Cultural Studies Review, vol. 14, no. 2, September 2008, p. 148. http://epress.lib.uts.edu.au/journals/index.php/csrj/article/view/2077

38 See also Joan Martin, 'The Homeswest Incident', in Joan Martin and Bruce Shaw, Joan Martin (Yarrna): A Widi Woman, Aboriginal Studies Press, Canberra, 2011, pp. $145^{-8}$.

39 Meaghan Morris, 'Crazy Talk is not Enough: Deleuze and Guattari at Muriel's Wedding' in her Identity Anecdotes: Translation and Media Culture, Sage Publications Ltd, London, 2006, p. 190. 